\title{
PENGARUH MODEL PEMBELAJARAN VAN HIELE TERHADAP KEMAMPUAN KONEKSI MATEMATIS SISWA SMP
}

\author{
${ }^{1)}$ Hamidah, ${ }^{2)}$ Siti Chotimah \\ ${ }^{1)}$ shiroimida@gmail.com, ${ }^{2 .)}$ chotie_pis@yahoo.com \\ ${ }^{1,2)}$ Program Studi Pendidikan Matematika, STKIP Siliwangi
}

\begin{abstract}
ABSTRAK
Latarbelakang penelitian ini yaitu keterampilan yang baik dalam geometri mampu mendukung pamahaman siswa terhadap ilmu lain dalam matematika seperti ilmu menghitung, mengukur, dan lainlain. Namun kenyataannya, geometri merupakan salah satu pokok bahasan yang kebanyakan tidak disukai oleh siswa. Kemampuan koneksi matematis merupakan salah satu kemampuan yang diperlukan dalam memahami geometri. Terdapat lima fase berpikir dalam model Van Hiele yang memberi pengaruh positif terhadap kemampuan koneksi matematis siswa. Penelitian ini merupakan eksperimen dengan disain pretest-postest control group design. Populasi dalam penelitian ini adalah seluruh siswa SMP kelas VII di Ciomas, sedangkan sampelnya adalah siswa kelas VII dari salah satu SMP di Ciomas yang ditetapkan secara purposive dan dipilih dua kelas VII secara acak dari kelas VII yang ada. Data hasil penelitian akan dianalisis dengan menggunakan uji statistic $\mathrm{t}$, uji koefisien kontingensi dan uji dengan statistik chi kuadrat. Berdasarkan analisis data kuantitatif, diperoleh kesimpulan bahwa kemampuan koneksi matematis siswa SMP yang memperoleh model pembelajaran Van Hiele lebih baik daripada yang memperoleh pembelajaran biasa.
\end{abstract}

Kata Kunci: Koneksi Matematis dan Pembelajaran Van Hiele

\begin{abstract}
Background This study is a good skill in geometry capable of supporting pamahaman students towards other disciplines in mathematics as the science of counting, measuring, and others. But in reality, the geometry is one of the topics that most disliked by students. Mathematical connection capability is one of the necessary capabilities in understanding geometry. There are five phases in the model Van Hiele thinking that gave a positive influence on students' mathematical connection capabilities. This research is an experimental design with pretest-posttest control group design. The population in this study are all junior high school students of class VII in Ciomas, while the sample is a class VII student of one junior high school in Ciomas defined two classes purposive and selected randomly from class VII VII there. Research data will be analyzed using statistical $t$ test, contingency coefficient test and chi squared test statistics. Based on the analysis of quantitative data, we concluded that the mathematical connection ability of junior high school students who acquire Van Hiele learning model is better than the usual learning gain.
\end{abstract}

Keywords: Mathematical Connections and Learning Van Hiele

\section{A. PENDAHULUAN}

Matematika merupakan salah satu pelajaran yang erat kaitannya dengan kehidupan nyata. Tidak sedikit hal maupun masalah yang ada disekeliling kita memerlukan ilmu matematika. Geometri merupakan salah satu cabang ilmu matematika yang paling mudah dikaitkan dengan kehidupan nyata. Dengan demikian seharusnya cabang ilmu ini relatif mudah disampaikan oleh guru dan dipahami oleh siswa. Namun kenyataannya, geometri merupakan salah satu pokok bahasan yang kebanyakan tidak disukai oleh siswa. Wardhani \& Rumiati (Safrina, 2014) menjelaskan bahwa hanya $20 \%$ siswa Indonesia dapat menjawab dengan benar salah satu soal pemecahan masalah geometri mengenai konsep keliling persegi, persegi panjang dan jajargenjang.

Geometri memiliki peran yang cukup besar terhadap proses berpikir siswa serta memiliki banyak keterkaitan dengan materi pada pelajaran 
lain. Seperti yang diungkapkan Kennedy \& Tipps (Kania, 2010) bahwa dengan pembelajaran geometri mampu mengembangkan kemampuan pemecahan masalah dan mendukung banyak topik lain dalam matematika.

Namun demikian, pada kenyataan di lapangan banyak dijumpai gaya mengajar guru yang belum maksimal sehingga hasil belajar siswa belum efisien. Hasil penelitian Suryadi (2004) menunjukkan bahwa pembelajaran matematika pada umumnya masih berfokus pada pengembangan kemampuan berpikir tahap rendah yang prosedural. Usiskin (1982) menyebutkan bahwa salah satu faktor yang memberi pengaruh besar terhadap kemampuan matematika siswa adalah kualitas dari pembelajaran matematika. Untuk itu perlu satu pembelajaran yang berkualitas yang mampu memberi pengaruh besar terhadap kemampuan matematik khususnya kemampuan koneksi matematis siswa. Salah satu pembelajaran tersebut adalah model pembelajaran Van Hiele.

Terdapat lima fase berpikir dalam model pembelajaran Van Hiele yaitu fase pengenalan, analisis, pengurutan, deduksi, dan akurasi. Burger (1986) menyebutkan pembelajaran geometri Van Hiele mampu mengajak siswa untuk mengeksplor kemampuannya dalam melihat beberapa karakteristik yang berkaitan dengan matematika khususnya geometri serta mengajak siswa untuk berpartisipasi aktif secara rutin selama proses pembelajaran.

Fase-fase dalam model pembelajaran Van Hiele mampu memberi kontribusi terhadap kemampuan koneksi dan abstraksi matematis siswa. Tahapan dalam proses pembelajaran Van Hiele mengajak siswa untuk melakukan pengurutan, dengan kata lain siswa dibiasakan menemukan keterkaitan antar konsep dari materi yang sedang dipelajari. NCTM (1989) menyebutkan bahwa kemampuan koneksi matematik adalah kemampuan dalam melihat hubungan antara dua representasi yang ekuivalen. Sejalan dengan latar belakang tersebut, penelitian ini mengambil judul "Pengaruh Model Pembelajaran Van Hiele Terhadap Kemampuan Koneksi Matematis Siswa SMP”.

Secara umum rumusan masalah dalam penelitian ini: apakah kemampuan koneksi matematis siswa SMP yang memperoleh model pembelajaran Van Hiele lebih baik daripada yang memperoleh pembelajaran biasa?
Penelitian ini bertujuan untuk menelaah peranan model pembelajaran Van Hiele terhadap kemampuan koneksi matematis siswa SMP.

Berikut ini disajikan definisi operasional variabel yang terlibat dalam penelitian ini.

1. Kemampuan koneksi matematik adalah kemampuan dalam melihat hubungan antar konsep dalam matematika. Adapun indikatornya yaitu:

a. Mengenali dan menggunakan hubungan antar ide-ide dalam matematika

b. Memahami keterkaitan ide-ide matematika dan membentuk ide satu dengan yang lain sehingga menghasilkan suatu keterkaitan yang menyeluruh

c. Mengenali dan mengaplikasikan matematika ke dalam dan lingkungan di luar matematika

2. Model pembelajaran Van Hiele adalah model pembelajaran yang dalam prosesnya terdiri dari lima fase berpikir deduksi, dan akurasi.

\section{B. KAJIAN TEORI DAN METODE}

\section{Kajian Teori}

\section{a. Kemampuan Koneksi Matematis}

Kemampuan koneksi matematis merupakan kemampuan dalam melihat hubungan baik antar topik matematika maupun dalam bidang lain dan dalam kehidupan. NCTM (1989) meneyebutkan terdapat dua tipe umum dalam koneksi matematik yaitu modeling connection dan mathematical connection.

Selanjutnya, Sumarmo (2005) menyebutkan bahwa terdapat beberapa indikator dalam kemampuan koneksi matematis siswa yaitu: (1) mengenali representasi ekuivalen dari konsep yang sama; (2) mengenali hubungan prosesdur matematika suatu representasi ke prosedur representasi yang ekuivalen; (3) menggunakan dan menilai keterkaitan antar topik matematika dan keterkaitan diluar matematika; dan (4) menggunakan matematika dalam kehidupan sehari-hari. Hal ini jelas menunjukan bahwa tanpa kemampuan koneksi matematis, siswa harus mengingat banyak konsep dan prosedur matematika secara terpisah. Seperti yang diungkapkan (NCTM, 2000) yaitu jika siswa dapat menemukan keterkaitan ide-ide matematis dengan koneksi antar topik matematika, dengan bidang lain, maupun dengan pengalaman hidup sehari-harinya maka siswa dapat memahami 
konsep matematika tersebut secara mendalam dan lebih bertahan lama.

\section{b. Pembelajaran Van Hiele}

Menurut teori Van Hiele (1999) dalam mengajarkan geometri terdapat lima fase berpikir yang berurutan yang harus dilakukan yaitu fase pengenalan, analisis, pengurutan, deduksi, dan akurasi. Buhari (2011) menambahkan bahwa dengan lima fase berpikir tersebut dapat mengajak siswa untuk berpikir ke tingkat yang lebih tinggi atau dikenal dengan high order thinking.

Erdogan (2009), fase pengenalan merupakan fase menyampaikan informasi yaitu siswa dikenalkan dengan domain yang akan mereka pelajari yang kemudian mengenal contoh dan bukan contoh dari domain tersebut. Fase analisis atau guided orientation yaitu siswa diajak untuk menyelesaikan baik berdiksusi atau individu soal-soal yang harus memiliki hubungan antar konsep.

Fase pengurutan atau explicitation merupakan fase mengiring siswa untuk menuliskan relasi atau hubungan antar konsep pada fase analisis ke dalam bentuk gambar atau dengan kata-kata sendiri sesuai dengan topik yang sedang dibahas. Pada fase ini siswa menggunakan ide-ide mereka dalam mengungkap sifat-sifat dari topik yang sedang dibahas. Fase deduksi atau orientation merupakan fase yang mengajak siswa menyelesaikan soa-soal yang lebih kompleks dalam mengungkap dan mengidentifikasikan sifat-sifat dari topik yang dibahas. Terakhir adalah fase akurasi atau integration yaitu fase yang mengajak siswa untuk membuat ringkasan intisari materi yang mereka pelajari pada pertemuan dari fase pertama.

Implementasi pembelajaran geometri dengan teori belajar Van Hiele. Kegiatan belajar geometri dengan van hiele bermaksud untuk melatih kemampuan siswa berdasarkan tahapannya yaitu dimulai dari tahap visualisasi ke tahap analitik. Hal ini dikarenakan fase-fase pembelajaran geometri van hiele menyesuaikan dengan tahapan berpikir anak dengan memperhatikan tingkat kesukaran dimulai dari yang paling mudah samai ke tingkat yang lebih kompleks. Dengan fase-fase tersebut, guru dapat mengetahui perkembangan kognitif anak misalnya guru dapat mengetahui mengapa ada beberapa siswa belum memahami bahwa kubus merupakan balok atau guru dapat mengetahui mengapa masih ada siswa yang beranggapan bahwa persegi panjang bukan persegi.

\section{c. Studi yang Relevan}

Hasil penelitian Nopriana (2013) yaitu peningkatan kemampuan berpikir geometri siswa yang pembelajarannya menggunakan model pembelajaran geometri Van Hiele lebih baik daripada yang pembelajarannya menggunakan pembelajaran konvensional. Selanjutnya, hasil penelitian Hastuti (2004) diperoleh bahwa metode mengajar guru memberi pengaruh terhadap minat belajar siswa SMP. Hasil penelitian Permana (2004) yaitu kemampuan penalaran dan koneksi matematis siswa SMA yang diberikan pembelajaran berbasis masalah lebih baik daripada pembelajaran biasa.

\section{Metode}

Studi ini dirancang dalam bentuk eksperimen dengan disain pretest posttest control group design yang bertujuan menelaah peranan pembelajaran Van Hiele terhadap kemampuan koneksi dan abstraksi matematis serta minat belajar siswa SMP. Sampel ditetapkan secara acak yaitu yang menjadi kelas eksperimen dan kelas kontrol. Tes kemampuan koneksi dan abstraksi matematis siswa masing-masing disusun mengacu pada karakteristik kemampuan koneksi serta pedoman penyususunan tes yang baik. Data dianalisis dengan menggunakan uji statistik t.

Dengan demikian, desain penelitiannya (Ruseffendi, 2005) adalah sebagai berikut:

$$
\begin{array}{lllll}
A & : & O & X & O \\
A & : & O & & O
\end{array}
$$

Keterangan:

A : pemilihan sampel secara acak kelas

$\mathrm{O}$ : tes awal = tes akhir (tes kemampuan koneksi matematis)

$\mathrm{X}$ : perlakuan dengan model Pembelajaran Van Hiele

Untuk melihat langkah-langkah penelitian disajikan pada Tabel 1. sebagai berikut:

\begin{tabular}{|c|c|c|c|}
\hline $\begin{array}{c}\text { Sifat } \\
\text { Kajian }\end{array}$ & Metode & $\begin{array}{c}\text { Langkah } \\
\text { Penelitian }\end{array}$ & $\begin{array}{l}\text { Luaran yang } \\
\text { diharapkan }\end{array}$ \\
\hline $\begin{array}{l}\text { Teoritis, } \\
\text { Empiris }\end{array}$ & $\begin{array}{l}\text { Studi } \\
\text { teoritik } \\
\text { dokument } \\
\text { asi }\end{array}$ & $\begin{array}{l}\text { Identifikasi } \\
\text { kemampuan } \\
\text { koneksi } \\
\text { matematis, } \\
\text { materi ajar, } \\
\text { serta kondisi }\end{array}$ & $\begin{array}{l}\text { Data tentang } \\
\text { kondisi awal dan } \\
\text { kesulitan belajar } \\
\text { siswa }\end{array}$ \\
\hline
\end{tabular}

Tabel 1. Langkah-Langkah Penelitian 


\begin{tabular}{|c|c|c|c|}
\hline $\begin{array}{l}\text { Teoritis } \\
\text { Rasional } \\
\text { Empiris }\end{array}$ & $\begin{array}{l}\text { Studi } \\
\text { analisis } \\
\text { deskriptif }\end{array}$ & $\begin{array}{l}\text { Merancang } \\
\text { sampel bahan } \\
\text { ajar dan } \\
\text { instrumen } \\
\text { untuk } \\
\text { penelitian. }\end{array}$ & $\begin{array}{l}\text { Rancangan } \\
\text { bahan ajar dan } \\
\text { instrumen } \\
\text { berkenaan } \\
\text { dengan } \\
\text { kemampuan } \\
\text { koneksi } \\
\text { matematis dan }\end{array}$ \\
\hline $\begin{array}{l}\text { Teoritis } \\
\text { Rasional } \\
\text { Empiris }\end{array}$ & $\begin{array}{l}\text { Studi } \\
\text { analisis } \\
\text { deskriptif }\end{array}$ & $\begin{array}{l}\text { Mengujicoba } \\
\text { sampel bahan } \\
\text { ajar dan } \\
\text { instrumen. }\end{array}$ & $\begin{array}{l}\text { Bahan ajar dan } \\
\text { tes kemampuan } \\
\text { koneksi } \\
\text { matemat is siswa }\end{array}$ \\
\hline $\begin{array}{l}\text { Rasional } \\
\text { Empiris } \\
\text { naturalist }\end{array}$ & $\begin{array}{l}\text { Studi } \\
\text { analisis } \\
\text { deskriptif, }\end{array}$ & $\begin{array}{l}\text { Melaksanakan } \\
\text { penelitian } \\
\text { dalam hal } \\
\text { melakukan } \\
\text { pembelajaran, } \\
\text { analisis data, } \\
\text { analisis } \\
\text { pelaksanaan } \\
\text { pembelajaran, } \\
\text { laporan, } \\
\text { lampiran dan } \\
\text { seminar } \\
\text { /publikasi } \\
\text { hasil }\end{array}$ & $\begin{array}{l}\text { Laporan } \\
\text { Penelitian dan } \\
\text { artikel untuk } \\
\text { seminar dan/atau } \\
\text { dimuat dalam } \\
\text { jurnal } \\
\text { ilmiah ber-issn } \\
\text { bertaraf nasional } \\
\text { terakreditasi } \\
\text { dan/atau } \\
\text { prosiding yang } \\
\text { bertaraf } \\
\text { nasional/internasi } \\
\text { onal. }\end{array}$ \\
\hline
\end{tabular}

Data hasil tes (postes maupun retensinya) kedua kelompok diolah dengan menggunakan bantuan SPSS 19 dengan langkah, yaitu: a) menghitung rata-rata dan simpangan baku; b) menguji normalitas data sampel; dan c) Uji Perbedaan RataRata.

\section{HASIL DAN PEMBAHASAN}

Pengolahan data tes kemampuan koneksi matematis didasarkan pada skor pretes dan skor postes. Skor pretes dan postes untuk kelas ekserimen dan kelas kontrol terdapat dalam lampiran. Dari skor-skor tersebut, nilai rata-rata $(\bar{x})$ dan simpangan baku (s) untuk masing-masing kelas dapat diketahui. Berikut ini tabel yang memuat nilai-nilai deskripsi hasil penelitian untuk masing-masing kelas.

Tabel 2. Deskripsi Data Kemampuan Koneksi Matematis Siswa

\begin{tabular}{lccccc}
\hline \multirow{2}{*}{ Variabel } & \multirow{2}{*}{ Ket. } & \multicolumn{2}{c}{ Kelas } & \multicolumn{2}{c}{ Kelas } \\
& & Pre & Pos & Kontrol \\
& $\mathrm{n}$ & 32 & 32 & 32 & Pos \\
\hline & $x_{\text {maks }}$ & 5 & 12 & 5 & 10 \\
Kemampuan & $x_{\text {min }}$ & 0 & 6 & 0 & 3 \\
Koneksi & $\bar{x}$ & 2,34 & 9 & 2,53 & 6,78 \\
Matematis & $*(\%)$ & $(19,5)$ & $(75)$ & $(21,1)$ & $(56,5)$ \\
& $\mathrm{s}$ & 1,734 & 2,286 & 1,741 & 2,393 \\
& & & & & \\
\hline
\end{tabular}

Skor Maksimal Ideal Kemampuan Koneksi Matematis $=12$

*) Diperoleh dari pembagian antara skor rata-rata dengan skor maksimal ideal dikalikan 100

Berdasarkan deskripsi data mentah pada tabel di atas, diperoleh standar deviasi untuk pretes kemampuan koneksi matematis kelas eksperimen adalah 1,734 sedangkan kelas kontrol 1,741, artinya pada kelas kontrol kemampuan awal koneksi matematisnya lebih menyebar dari pada kelas eksperimen. Selanjutnya, standar deviasi untuk postes kemampuan koneksi matematis kelas eksperimen adalah 2,286 sedangkan kelas kontrol 2,393, artinya pada kelas kontrol kemampuan koneksi matematisnya lebih menyebar dari pada kelas eksperimen.

Dari tabel di atas, dapat dilihat bahwa skor ratarata pretes kemampuan koneksi matematis kelas eksperimen sebesar 2,34 dan kelas kontrol sebesar 2,53, dari kedua data tersebut diperoleh selisih sebesar 0,19 . Selisih persentasi rata-rata pretes kemampuan koneksi kelas eksperimen dan kelas kontrol yaitu $1,58 \%$ dari rata-rata skor idealnya. Nilai ini menunjukan bahwa nilai kelas kontrol lebih tinggi dari kelas eksperimen dengan selisih data dari kedua kelas tersebut tidak terlalu besar. Dapat diduga bahwa kedua kelas memiliki kemampuan awal koneksi matematis yang tidak jauh berbeda, namun secara umum kemampuan awal kelas kontrol lebih baik dari kelas eksperimen.

Selanjutnya dari tabel di atas, dapat dilihat bahwa skor rata-rata postes kemampuan koneksi matematis kelas eksperimen sebesar 9 dan kelas kontrol sebesar 6,78, dari kedua data tersebut diperoleh selisih sebesar 2,22. Selisih persentasi rata-rata postes kemampuan koneksi matematis kelas eksperimen dan kelas kontrol yaitu 18,5\% dari rata-rata skor idealnya. Nilai ini menunjukan bahwa nilai kelas eksperimen lebih tinggi dari kelas kontrol dengan selisih data dari kedua kelas tersebut cukup besar. Dapat diduga bahwa kedua kelas memiliki kemampuan koneksi matematis yang berbeda, dan secara umum kemampuan koneksi kelas eksperimen lebih baik dari kelas kontrol.

Berdasarkan analisis dari data mentah tabel 2, dapat disimpulkan bahwa secara umum kedua kelas yaitu kelas eksperimen dan kelas kontrol memiliki kemampuan awal koneksi matematis 
yang tidak jauh berbeda. Setelah pembelajaran berlangsung, secara umum diketahui kemampuan koneksi matematis untuk kelas eksperimen mangalami peningkatan yang lebih baik daripada kelas kontrol. Namun demikian, data tersebut belum dapat dipastikan signifikan atau tidaknya, maka dari itu selanjutnya dilakukan uji statistik.

Hasil uji statistik untuk data pretes menunjukan bahwa tidak terdapat perbedaan kemampuan awal koneksi matematis siswa kelas eksperimen dan kelas kontrol. Sedangkan hasil uji statistik data postes dapat dilihat pada tabel berikut:

\begin{tabular}{|c|c|}
\hline \multicolumn{2}{|c|}{ Test Statistics $^{\mathrm{a}}$} \\
\hline & Pos_Koneksi \\
\hline Mann-Whitney U & 259.000 \\
\hline Wilcoxon W & 787.000 \\
\hline Z & -3.426 \\
\hline Asymp. Sig. (2-tailed) & .001 \\
\hline
\end{tabular}

Dari output pada Tabel 3. diketahui nilai Asymp.Sig sebesar 0,001. Karena nilai Asymp.Sig $0,001<0,05$ maka sesuai dengan dasar pengambilan keputusan dalam uji MannWhitney dapat disimpulkan bahwa Ho ditolak yang artinya kemampuan koneksi matematis siswa SMP yang memperoleh model pembelajaran Van Hiele lebih baik daripada yang memperoleh pembelajaran biasa

\section{KESIMPULAN}

Berdasarkan hasil analisis dan pembahasan serta temuan-temuan yang diperoleh dalam penelitian ini, maka dapat disimpulkan bahwa kemampuan koneksi matematis siswa SMP yang memperoleh model pembelajaran Van Hiele lebih baik daripada yang memperoleh pembelajaran biasa.

\section{E. DAFTAR PUSTAKA}

Buhari, B. 2011. Teori Level Van Hiele dalam Pembelajaran Geometri. Tersedia pada http://bustangbuhari.wordpress.com.

Diakses tanggal 28 Juni 2012.

Burger, W.F. \& Shaughnessy, J.M.. 1986. Characterizing the van Hiele Levels of Development in Geometry. Journal for Research in Mathematics Education. 17(I):31-48
Erdogan, et al. 2009. The Effect of the Van Hiele Model Based Instruction on the Creative Thinking Levels of $6^{\text {th }}$ Grade Primary School Students. Educational Science: Theory \& Practice. 9 (1). 181-194

Hastuti, N. P. 2004. Hubungan Antara Persepsi terhadap Metode Mengajar Guru dengan Minat Belajar Matematika Siswa SMP. Skripsi (Tidak Diterbitkan). Yogyakarta: Fakultas Psikologi Universitas Gadjah Mada

Kania, A. 2010. Peningkatan Level Berpikir Geometri Van Hiele melalui Pembelajaran Berbasis Masalah Berbantuan Cabry Geometry. Skripsi. FPMIPA UPI

NCTM. 1989. Curriculum and Evaluation Standards for School Mathematics. Reston, VA: Authur

NCTM. 2000. Principles and Standards for School Mathematics. Virginia: The NCTM, Inc..

Nopriana 2013. Peningkatan Kemampuan Berpikir Geometri dengan Pembelajaran Van Hiele di SMP. Skripsi UPI. Bandung. Tidak diterbitkan

Permana, Y. 2004. Pengembangan Kemampuan Penalaran dan Koneksi Matematis Siswa SMA melalui Pembelajaran Berbasis Masalah. Tesis PPS UPI. Bandung: Tidak diterbitkan

Ruseffendi, H.E.T. 2005. Dasar-Dasar Penelitian dan Bidang Non-Eksakta lainnya. Bandung: Tarsito

Safrina, K. 2014. Peningkatan Kemampuan Pemecahan Masalah Geometri melalui Pembelajaran Kooperatif Berbasis Teori Van Hiele. (Online). (file:///C:/Documents\%20and\%20Settings/ Mr.\%20Sutia/My\%20Documents/Downlo ads/1333-2528-1-SM\%20(1).pdf , diakses 3 Oktober 2014)

Sumarmo, U. 2005. Pembelajaran matematika untuk mendukung pelaksanaan kurikulum tahun 2002 sekolah menengah. Makalah Disajikan pada Seminar Pendidikan Matematika di FPMIPA Universitas Negeri Gorontalo: Tidak diterbitkan.

Suryadi, D. 2004. Landasan Teoritik Pembelajaran Berpikir Matematika. [Online]. Tersedia di: www.didi_suryadi.staf.upi.edu.html. Diakses 16 Maret 2012.

Usiskin, Z. 1982. Van Hiele Levels and Achievement in Secondary School Geometry. (Final report of the Cognitive Development and Achievement in Secondary School Geometry 
Project.) Chicago: University of Chicago. (ERIC Document Reproduction Service No. ED220288)

Van Hiele, P.M. 1999. Developing Geometric Thinking Through Activities That Begin With Play. Teaching Children Mathematics. (pp 310-316). Reston VA: National Council of Teachers of Mathematics 